\title{
ADDITIONAL GREAT GRAY OWL RECORDS FOR MANITOBA AND ADJACENT MINNESOTA
}

\author{
By Robert W. Nero, Manitoba Museum of Man \& Nature
}

A large influx of Great Gray Owls (Strix nebulosa) was reported for the 1968-69 winter season in southeastern Manitoba (Blue Jay 27, 191-209). The present note records some additional data in that connection and documents a minor influx for the winter of 1969-70.

A discussion of a reported influx in southern Manitoba for the winter of 1922-23 (op. cit.) overlooked supporting records at Grafton, North Dakota, 112 miles south of Winnipeg. Of three records for this species at Grafton during the period 1900-23, two are for the winter of 1922-23 (DecemberJanuary) (H. V. Williams. 1926. Birds of the Red River Valley of northeastern North Dakota. Wilson Bulletin, 38:17-33, 91-110).

Another summer record, presumably outside the breeding range, has been reported for Sandy Hook on the southern end of Lake Winnipeg, about 40 miles north of Winnipeg. Mrs. A. Elliott reports (pers. corres., April 13, 1970 ) that one was seen on several occasions in that vicinity from June 22, 1969 into mid-July 1969.

Records for the fall and winter of 1969-70 are given in Table 1 . The October 5 record at Makinak, just northeast of Riding Mountain National Park, is the second record for the park vicinity. John E. Mason, an active birder from Toronto, told me he saw this bird near a deciduous woodlet; it hooted a few times while being observed. Except for this record and a January 15 report for Duck Mountain Provincial Park, all records are for the southeastern corner of the province, from Pinawa south, the area in which most previous observations have been made. There are three main locations in which owls appeared this past winter: Pinawa-Seven Sisters, one or two birds; East Braintree-Richer, two

Table 1. Great Gray Owls records, 1969-70

\begin{tabular}{|c|c|c|c|c|}
\hline October & 5 & 1 seen & Makinak (3 mi. SW) & J. E. Mason \\
\hline December & $r 1$ & $\begin{array}{l}1 \text { captured ar } \\
\text { released }\end{array}$ & East Braintree ( $3 \mathrm{mi}$. NE) & G. M. Hornick \\
\hline$"$ & 7 & 1 seen & Richer ( $8 \mathrm{mi}$. SE) & $\begin{array}{l}\text { Mr. and Mrs. } \\
\text { A. F. Holloway }\end{array}$ \\
\hline$"$ & 11 & 1 seen & East Braintree (3 mi. S) & M. Yaremchuk \\
\hline$"$ & 28 & 1 seen & Pinawa $(6 \mathrm{mi} . \mathrm{W})$ & J. A. Frederich \\
\hline January & 2 & 1 seen & Richer (10 mi. SE) & M. J. Majure \\
\hline$"$ & 15 & 1 seen & Duck Mt. (junc. no's $366 \& 367$ ) & J. D. Robertson \\
\hline$"$ & 18 & 1 seen & Seven Sisters Falls ( $5 \mathrm{mi} . \mathrm{E}$ ) & B. Richter \\
\hline February & 7 & 1 seen & Pinawa vicinity & T. T. Vandergraaf \\
\hline March & 7 & 1 seen & Pinawa vicinity (same place) & T. T. Vandergraaf \\
\hline April & 1 & 8 seen & Sprague (7 mi. SW) (in U.S.) & Dr. H. T. Birks \\
\hline$"$ & 2 & 1 seen & (1 mi. N) & R. Kemp, L. Yarr \\
\hline$"$ & 4 & 2 seen & (14 mi. NE) & G. G. Graham \\
\hline , & 4 & 2 found dead & (7 mi. SW) (in U.S.) & Dr. H. T. Dirks \\
\hline$"$ & 5 & 1 seen & Anola ( $7 \mathrm{mi} . \mathrm{E})$ & G. Cotter \\
\hline$"$ & 7 & 1 seen & Sprague (7 mi. SW) (in U.S.) & R. Hobbs \\
\hline$"$ & 9 & 1 seen & $"$ & R. Hobbs \\
\hline$"$ & 11 & 3 found dead & $"$ & R. W. Nero \\
\hline$"$ & 12 & 1 seen & $\left(1 \frac{1}{2} \mathrm{mi} \cdot \mathrm{W}\right)$ & J. Urbanski \\
\hline$"$ & 21 & 1 seen & East Braintree (5 mi. SW) & G. G. Graham \\
\hline
\end{tabular}


or three birds; and Sprague, probably a dozen or more birds.

The Great Gray Owl captured on December 1 was caught accidentally by one foot in a steel trap set for lynx. Its toes were frozen fast to the trap and in order to free the owl the trapper had to sever its foot. It flew up to a nearby tree and eventually flew away. The owl had stepped into one of several traps set in a circle beneath an overhanging carcass of a Ruffed Grouse, a set-up favoured by trappers for taking lynx. This provides somewhat indirect evidence that the Great Gray Owl will occasionally prey on grouse.

Judging by reports received from several sources, Great Gray Owls appeared in early March along the international border south of South Junction and Sprague (or, from the Minnesota point of view, north of Roseau and Warroad). A maximum count of eight was made by Dr. H. T. Dirks at about 9:00 or 10:00 a.m. on April 1 within two miles south of the U.S. customs station near South Junction. Dr. Dirks, upon returning to Canada on April 4 at mid-day, found two dead owls in the same area. One was known to have been struck by a truck that morning; the other appeared to have been shot. On April 11, I found three dead owls, and on May 2, two more, along this same stretch of road. At least four of these appeared to have been shot. Customs officer Ray Hobbs reported having seen three dead ones, each at the bottom of a telephone pole, during this period. Thus, at least six, and possibly one or more additional owls, were killed along this section of road. The road for a few miles south of the station is or was bordered by large tracts of black spruce. Loggers cutting spruce along this particular stretch of road in March and April were thought by Hobbs to have been shooting owls, in spite of his protests.

Another dead owl, presumably a road kill of this species, was reported near Middleboro, but we were unable to locate it. Other large, dark owls were reported by customs officers in the area east of Middleboro. Evidently some 12 or 15 birds were concentrated in this general area. The appearance of owls over a period of several weeks in a limited area along the roadway south of the U.S. customs station is similar to what has previously been reported for this species in Manitoba and Minnesota. It suggests that the Great Gray Owl travels and winters in loose flocks, possibly comprised of one or more family groups. The presence of a large number of owls in this area in March and April is surprising, considering the relatively low numbers reported in the region to the north where numerous persons have been alerted to watch for these owls. One wonders where these birds were prior to their appearance in this area.

The accidental loss of wintering Great Gray Owls can hardly be controlled, but shooting ought to be stopped. The occurrence of Great Gray Owls in suitable nesting habitat in southeastern Manitoba in late April suggests the possibility of their nesting here, but shooting probably eliminates them. The necessity for continued widespread efforts to acquaint the public with birds of prey, their values, and even the laws protecting them should be made clear to educators and conservationists. A new policy established recently by the Manitoba Department of Mines and Natural Resources is a further step in this direction. In Manitoba, from now on, according to department officials, it will be difficult for anyone not connected with an educational institution or conservation group to obtain a permit to have mounted and to possess a dead hawk or owl or any other bird that is protected by law. This commendable viewpoint should be recommended to resource departments in other provinces and states.

An active Great Gray Owl nest found in the Roseau, Minnesota area and verified by us on May 2, is firm evidence that Great Gray Owls can and will nest in this region. With adequate protection this interesting bird could possibly become a regular member of the avifauna of southeastern Manitoba. 